\title{
PENENTUAN UMUR SIMPAN CUKA KAKAO MENGGUNAKAN METODE ACCELERATED SHELF-LIFE TESTING (ASLT) DENGAN PENDEKATAN ARRHENIUS
}

\author{
Ni Wayan Sukmayanti1 ${ }^{1}$, G.P. Ganda Putra², Lutfi Suhendra² \\ ${ }^{1}$ Mahasiswa Jurusan Teknologi Industri Pertanian, Fakultas Teknologi Pertanian Unud \\ ${ }^{2}$ Dosen Teknologi Industri Pertanian, Fakultas Teknologi Pertanian Unud \\ Email: wayansukmayanti95@gmail.com ${ }^{1}$ \\ Email koresponden: gandaputra@unud.ac.id ${ }^{2}$
}

\begin{abstract}
Cocoa vinegar is a fermented vinegar produced from a product of cocoa bean fermentation. The aims of this study were to determine quality change of cocoa vinegar during retention and determine its self-life by using Accelerated Shelf-Life Testing (ASLT) method by Arrhenius Equation Approach. This research was conducted by using one factor, and it was storage temperature treatment that consisting of 3 levels, 30,40 and $50^{\circ} \mathrm{C}$. Retention and observation start from 0 week until 16 weeks, with parameters that observe were acetic acid, $\mathrm{pH}$, total suspended solid and turbidity. Cocoa vinegar has decreased quality during storage, at $30^{\circ} \mathrm{C}, 40^{\circ} \mathrm{C}$ and $50^{\circ} \mathrm{C}$. During storage of the three temperatures, the temperature of $50^{\circ} \mathrm{C}$ suffered the most rapid deterioration with the characteristic of decreasing the acetic acid content by more than $50 \%$, and the increase of $\mathrm{pH}$, total suspended solid and turbidity on the 63rd day. Shelf life of cocoa vinegar by using the characteristic of acetic acid with linear regression equation $y=$ $-4624 . \mathrm{x}+10.30$ with $\mathrm{R}^{2}=0.999$.at storage from temperature $10,20,30,40$, and $50^{\circ} \mathrm{C}$ respectively were 431 days (14.3 months). 246 days ( 8.20 months). 146 days (4.86 months). 89 days ( 2.96 months).and 56 days (1.86 months).
\end{abstract}

Keywords: vinegar of cocoa, self-life prediction, ASLT method

\section{PENDAHULUAN}

Tanaman kakao (Theobroma cacao L) adalah tanaman perkebunan yang berasal dari hutan tropis. Tanaman kakao dikelompokkan menjadi 3 jenis yaitu, Forastero, Criollo, dan Trinitario yang merupakan hasil persilangan antara Forastero dengan Criollo. Fermentasi biji kakao menghasilkan limbah cair berupa cairan pulpa yang mengandung asam asetat $1,6 \%$, etil alkohol $0,5 \%$, asam sitrat $0,5 \%$ dan pH 6,5 (Case, 2004). Cairan pulpa biji kakao biasanya dianggap limbah dan jarang dimanfaatkan. Cairan yang keluar selama proses fermentasi berlangsng berkisar antara $15-20 \%$ dari berat biji yang difermentasi (Ganda-Putra et al., 2008). Berdasarkan penelitian Aridona et al. (2015), cairan pulpa dapat dimanfaatkan menjadi salah satu produk yang memiliki nilai jual lebih tinggi, salah satunya cuka fermentasi. Cuka fermentasi merupakan produk cair yang mengandung asam asetat, diperoleh melalui proses fermentasi bahan-bahan yang mengandung karbohidrat atau alkohol dengan atau tanpa penambahan bahan tambahan makanan yang diizinkan (SNI 01-4371-1996).

Industri makanan, menggunakan asam asetat sebagai pengatur_keasaman. (Yellisa, 2014). Asam cuka adalah produk yang umumnya digunakan sebagai bahan pengawet makanan, namun jika penyimpanan produk tidak diperhatikan, cuka juga dapat mengalami kerusakan. Penyimpanan yang kurang baik dapat menyebabkan aroma cuka berkurang dan tingkat keasaman menurun. Setiap produk pangan memiliki masa simpan (self life) yang berbeda-beda. Penyimpanan sangat berpengaruh terhadap kualitas dan mutu dari produk. Penentuan umur simpan produk pangan dapat dilakukan dengan menyimpan produk pada kondisi penyimpanan yang sebenarnya hingga produk tersebut mengalami 
kerusakan maksimal atau sering disebut dengan Extended Storage Studies (ESS). Cara ini dapat menghasilkan hasil yang tepat dan akurat, namun biasanya memerlukan waktu yang lama dan biaya yang besar. Selain itu pendugaan umur simpan pada produk juga dapat dilakukan dengan metode Accelerated Shelf-Life Testing (ASLT), yaitu dengan penyimpanan produk pangan pada lingkungan yang menyebabkan terjadinya kerusakan dengan cepat, baik pada kondisi suhu atau kelembaban ruang penyimpanan yang lebih tinggi dari pada kondisi sebenarnya. Metode ASLT yang sering digunakan adalah dengan model Arrhenius dan model kadar air kritis (Kusnandar, 2010). Menurut Herawati (2008), informasi umur simpan produk merupakan informasi yang wajib dicantumkan oleh produsen, pada label kemasan produk pangan. Umur simpan produk pangan berkaitan dengan keamanan produk pangan dan memberikan jaminan mutu pada saat produk sampai ke tangan konsumen. Penentuan umur simpan cuka kakao fermentasi dihitung dengan menggunakan persamaan kinetika reaksi berdasarkan orde reaksinya, yaitu jika reaksi berlangsung pada orde nol maka, ts $=(\mathrm{A} 0-\mathrm{At}) / \mathrm{k} \ldots \ldots \ldots \ldots \ldots(0)$ sedangkan untuk orde 1 adalah ts $=(\ln \mathrm{A} 0 / \mathrm{A}) / \mathrm{k} \ldots \ldots \ldots \ldots \ldots$ (1)...... Beberapa kajian pustaka produk pada penelitian sebelumnya yang menggunakan metode accelerated shelf-life testing (ASLT) dengan pendekatan arrhenius diantaranya.

Menurut Wijaya (2007) pendugaan umur simpan produk kopi instan menggunakan metode Accelerated Shelf-Life Testing (ASLT) dengan pendekatan Arrhenius, diperoleh hasil, suhu $30^{\circ} \mathrm{C}, 45^{\circ} \mathrm{C}$ dan $50^{\circ} \mathrm{C}$ berturut-turut 632 hari, 430 hari, dan 381 hari. Menurut penelitian Haryati et al. (2015) mengenai pendugaan umur simpan pada produk tape ketan hitam Mojokerto hasil sterilisasi, pada suhu $30^{\circ} \mathrm{C}, 40^{\circ} \mathrm{C}$ dan $50^{\circ} \mathrm{C}$ berturut-turut 536,4 hari, 312,2 hari dan 213,5 hari. Sandana et al. (2011), pada produk sirup pala di masing-masing suhu penyimpanan, pada suhu $30^{\circ} \mathrm{C}, 35^{\circ} \mathrm{C}$ dan $40^{\circ} \mathrm{C}$ berturut-turut 12,7, 11,4 dan 10,3 minggu.

Cuka kakao yang terbuat dari hasil samping fermentasi biji kakao belum diketahui umur simpannya. Sehingga perlu dilakukan penelitian lebih lanjut, dengan tujuan : mengetahui perubahan karakteristik mutu cuka kakao selama penyimpanan dan menentukan umur simpan cuka kakao selama penyimpanan.

\section{METODE PENELITIAN}

\section{Tempat dan Waktu}

Penelitian ini dilakukan di Laboratorium Bioindustri, Laboratorium Rekayasa Proses dan Pengendalian Mutu, Laboratorium Analisis Pangan Fakultas Teknologi Pertanian Universitas Udayana. Penelitian ini dilaksanakan pada Agustus - November 2017.

\section{Bahan dan Alat}

Bahan utama pada penelitian ini adalah cuka kakao yang didapat pada penelitian sebelumnya yang difermentasi selama 30 hari. Cuka kakao tersebut kemudian di pasteurisasi pada suhu $65^{\circ} \mathrm{C}$ dan dikemas pada botol kaca kemudian disimpan untuk mengetahui umur simpan produk cuka fermentasi tersebut. 
Peralatan yang digunakan diantaranya: botol kaca kapasitas $100 \mathrm{ml}$, gunting, kertas label, timbangan analitik (Shimadzu), kertas saring, biuret, pH meter (Ditech), labu ukur (Iwaki), aluminium foil, tisu, botol sampel, lemari pendingin, spektrofotometer (Genesys 10S UV-VIS), autoclave (Hirayama), sentrifuse (Centurion Scientific), pipet tetes, tabung reaksi (Iwaki), erlenmeyer (Iwaki), Inkubator (Memmert), plastik.

\section{Rancangan Penelitian}

Penelitian ini dilakukan dengan menggunakan metode Accelerated Shelf-Life Testing (ASLT) berdasarkan pendekatan semi empiris dengan bantuan persamaan Arrhenius, dengan teori kinetika yang pada umumnya menggunakan ordo nol atau satu untuk pangan. Penelitian ini merupakan eksperimen yang dilakukan dengan menyimpan cuka kakao pada inkubator yang suhunya diatur untuk mengetahui perubahan karakteristik cuka kakao. Suhu yang digunakan adalah $30{ }^{\circ} \mathrm{C}, 40{ }^{\circ} \mathrm{C}$ dan $50^{\circ} \mathrm{C}$.

\section{Pelaksanaan Penelitian}

\section{Persiapan Bahan dan Penyimpanan Cuka Kakao}

Cuka kakao yang digunakan pada penelitian ini yaitu cuka yang diperoleh pada penelitian yang dilakukan sebelumnya, yaitu cuka fermentasi cairan pulpa kakao dari hasil fermentasi selama 30 hari. Cuka kakao yang telah selesai difermentasi dan dipasteurisasi terlebih dahulu selama 30 menit pada suhu $65^{\circ} \mathrm{C}$, kemudian didinginkan. Cuka kakao di kemas ke dalam botol kaca bening sebanyak $100 \mathrm{ml}$ dan disimpan masing-masing pada suhu 30,40 , dan $50^{\circ} \mathrm{C}$. Skema pelaksanaan penelitian disajikan pada Gambar 1.

\section{Penentuan Karakteristik Mutu Awal dan Mutu Akhir cuka kakao cairan pulpa kakao}

Cuka kakao hasil samping cairan pulpa kakao perlu diuji sebelum dilakukan penelitian untuk mengetahui karakteristik awalnya. Karakteristik yang dianalisis pada cuka kakao adalah kadar asam asetat, $\mathrm{pH}$, total padatan terlarut dan kekeruhan. Analisis ini dilakukan untuk mengetahui keadaan mutu awal $\left(\mathrm{A}_{0}\right)$ dan mutu akhir (At) produk cuka kakao sebelum disimpan sehingga dapat dilakukan penentuan umur simpan melalui identifikasi kerusakan-kerusakan selama proses penyimpanan pada cuka kakao. Karakteristik mutu akhir yang ditentukan apabila kadar asam asetat telah mengalami penurunan lebih dari $50 \%$ dari mutu awal $\left(\mathrm{A}_{0}\right)$ pada penyimpanan dan suhu kritis $\left(50^{\circ} \mathrm{C}\right)$.

\section{Penentuan Laju Penurunan Mutu dan Perhitungan Umur Simpan Cuka Kakao}

Data hasil analisis produk cuka kakao diplotkan terhadap waktu dan diperoleh persamaan regresi liniernya, kemudian diperoleh tiga persamaan regresi untuk 3 kondisi suhu penyimpanan dengan menggunakan $\mathrm{y}=\mathrm{a}+\mathrm{bx}$, jika $\mathrm{y}=$ nilai karakteristik cuka fermentasi, $\mathrm{x}=$ waktu penyimpanan (hari), $\mathrm{a}=$ nilai karakteristik mutu cuka kakao pada awal penyimpanan dan $b=$ laju perubahan nilai karakteristik. Berdasarkan masing-masing persamaan tersebut diperoleh nilai slope (b) yang merupakan konstanta laju reaksi perubahan karakteristik produk atau laju penurunan mutu (k). Untuk menentukan orde reaksi yang digunakan dibuat grafik orde nol yaitu hubungan antara nilai $\mathrm{k}$ dengan lama penyimpanan dan orde satu yaitu hubungan antara ln k dengan lama penyimpanan. Dari kedua persamaan tersebut dipilih $\mathrm{R}^{2}$ terbesar. 
Pendekatan Arrhenius, nilai k diplotkan terhadap 1/T (K-1) dan ln k, didapatkan nilai intersep dan slope dari persamaan regresi linier $\ln \mathrm{k}=\ln \mathrm{k} 0-(\mathrm{E} / \mathrm{R})(1 / \mathrm{T})$. Dimana $\ln \mathrm{k} 0=$ intersep, $\mathrm{E} / \mathrm{R}=$ slope, $\mathrm{Ea}=$ energi aktivasi dan $\mathrm{R}$ = kosntanta gas ideal $(1,986 \mathrm{kal} / \mathrm{mol})$. Dari persamaan tahap kelima diperoleh nilai konstanta k0 yang merupakan faktor eksponensial dan niai energi aktivasi reaksi perubahan karakteristik cuka fermentasi $(\mathrm{Ea}=\mathrm{E})$. Kemudian ditentukan model persamaan laju reaksi $(\mathrm{k})$ perubahan karakteristik cuka fermentasi dengan $\mathrm{k}=\mathrm{k} 0 . \mathrm{e}-\mathrm{E} / \mathrm{RT}$. Setelah didapatkan persamaan Arrhenius, dapat dihitung nilai konstanta Arrhenius (k) pada suhu (T) penyimpanan yang ditentukan. Penentuan karakteristik kunci dengan melihat karakteristik yang mempunyai energi aktivasi terendah. Umur simpan cuka fermentasi dihitung dengan menggunakan persamaan kinetika reaksi berdasarkan orde reaksinya, yaitu jika reaksi berlangsung pada orde nol maka ts $=(\mathrm{A} 0-\mathrm{At}) / \mathrm{k}$, sedangkan untuk orde satu adalah ts $=(\ln \mathrm{A} 0 / \mathrm{A}) / \mathrm{k}$. Penentuan umur simpan pada suhu normal adalah dengan memasukan nilai suhu (konversi ${ }^{0} \mathrm{C}$ menjadi $\left.{ }^{0} \mathrm{~K}\right)$ ke dalam persamaan $\ln \mathrm{k}=\ln \mathrm{k} 0-(\mathrm{E} / \mathrm{R})(1 / \mathrm{T})$ dan kemudian nilai $\mathrm{k}$ dimasukkan ke dalam persamaan orde reaksi untuk mendapatkan umur simpan cuka fermentasi kakao. Diagram alir penelitian dapat dilihat pada Gambar 1.

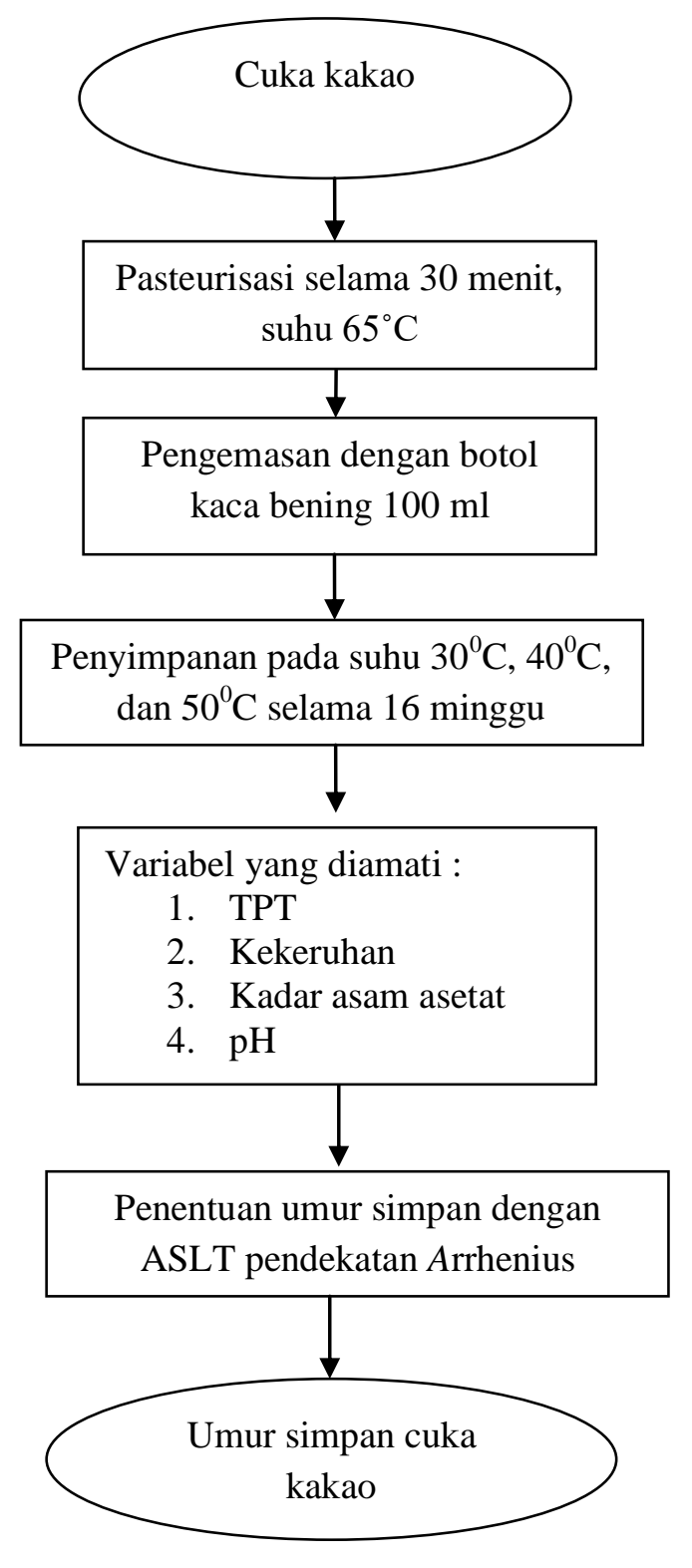

Gambar 1. Diagram alir pelaksanaan penelitian. 


\section{Variabel yang diamati}

Variabel yang diamati yaitu kadar asam asetat (SNI 01-3711-1995), pH (Apriyanto et al., 1988), total padatan terlarut (Wartini et al., 2014), dan Kekeruhan (Yanlinastuti, 2009).

\section{HASIL DAN PEMBAHASAN}

\section{Karakteristik Mutu Awal ( $\left.\mathbf{A}_{0}\right)$ dan Mutu Akhir (At) Cuka Kakao}

Selama proses penyimpanan berlangsung, terjadi penurunan kadar asam asetat pada cuka kakao di masing-masing suhu penyimpanan, yang diikuti dengan adanya peningkatan kadar $\mathrm{pH}$, TPT, dan kekeruhan. Mutu akhir cuka kakao $\left(\mathrm{A}_{\mathrm{t}}\right)$ ditentukan apabila kadar asam asetatnya mengalami penurunan lebih dari $50 \%$ dari mutu awalnya $\left(\mathrm{A}_{0}\right)$. Karakteristik mutu akhir $\left(\mathrm{A}_{\mathrm{t}}\right)$ cuka kakao ditentukan apabila kadar asam asetat mengalami penurunan terdapat pada hari ke-63. dapat di lihat pada Tabel 1.

Tabel 1. Karakteristik mutu awal $\left(\mathrm{A}_{\mathrm{o}}\right)$ dan mutu akhir (At) cuka kakao

\begin{tabular}{lcc}
\hline \multicolumn{1}{c}{ Karakteristik Mutu } & $\mathrm{A}_{\mathrm{o}}$ & $\mathrm{A}_{\mathrm{t}}$ \\
\hline Asam Asetat $(\% \mathrm{~b} / \mathrm{b})$ & 1,95 & 0,81 \\
$\mathrm{pH}$ & 4,12 & 5,03 \\
TPT $\left({ }^{\circ}\right.$ Brix $)$ & 4,70 & 5,18 \\
Kekeruhan & 2,90 & 7,90 \\
\hline
\end{tabular}

\section{Laju Perubahan Karakteristik Asam Asetat (\% b/b)}

Kadar asam asetat pada cuka kakao dari cairan pulpa hasil samping kakao mengalami penurunan selama penyimpanan, seperti pada Gambar 2. Perubahan kadar asam asetat selama penyimpanan berkisar $1,95-0,81(\% \mathrm{~b} / \mathrm{b})$.

Perubahan kadar asam asetat dipengaruhi oleh kenaikan suhu dan lama penyimpanann sehingga menyebabkan kadar asam mengalami penurunan dan kerusakan. Hal ini terjadi karena asam asetat mengalami oksidasi menjadi $\mathrm{CO}_{2}$ dan $\mathrm{H}_{2} \mathrm{O}$. (Leasa dan Matdoan, 2015). Laju perubahan kadar asam asetat cuka kakao hasil samping cairan kakao orde 0 dan orde 1 dapat dilihat pada Gambar 2. Persamaan regresi karakteristik asam asetat dapat dilihat pada Tabel 2.
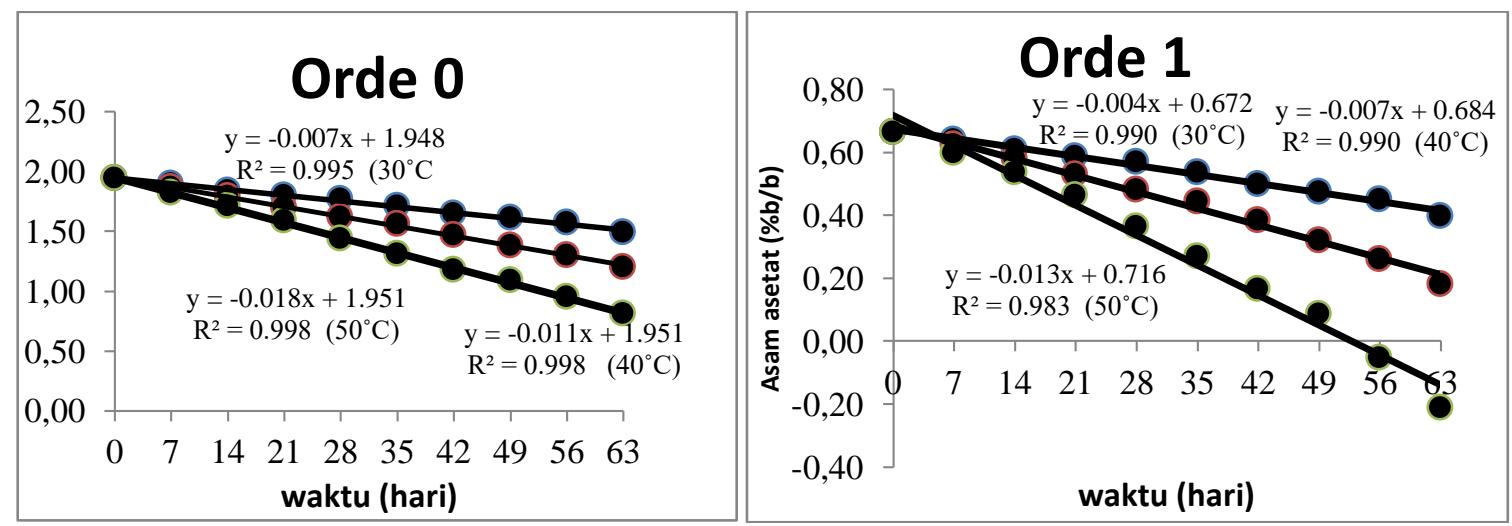

Gambar 2 Perubahan mutu asam asetat cuka kakao orde 0 dan orde 1. 
Tabel 2. Persamaan regresi linear karakteristik kadar asam asetat

\begin{tabular}{lccccc}
\multirow{2}{*}{ Parameter } & \multirow{2}{*}{\begin{tabular}{c} 
Suhu \\
\cline { 3 - 6 }
\end{tabular}} & \multicolumn{2}{c}{ Persamaan Regresi } & \multicolumn{2}{c}{$\mathrm{R}^{2}$ (R square) } \\
\cline { 3 - 6 } Asam & 30 & $\mathrm{y}=-0.007 \mathrm{x}+1.9487$ & $\mathrm{y}=-0.0041 \mathrm{x}+0.6721$ & 0.9950 & 0.9906 \\
Asetat & 40 & $\mathrm{y}=-0.0117 \mathrm{x}+1.9518$ & $\mathrm{y}=-0.0075 \mathrm{x}+0.6848$ & 0.9987 & 0.9906 \\
& 50 & $\mathrm{y}=-0.018 \mathrm{x}+1.9511$ & $\mathrm{y}=-0.0136 \mathrm{x}+0.7165$ & 0.9989 & 0.9833 \\
\hline
\end{tabular}

Tabel 2, menunjukkan penentuan umur simpan cuka kakao asam asetat dilakukan dengan menentukan orde reaksi persamaan regresi $\left(\mathrm{R}^{2}\right)$. Penentuan orde reaksi yang digunakan dapat dilihat dengan membandingkan nilai $\mathrm{R}^{2}$, yaitu dipilih $\mathrm{R}^{2}$ yang lebih tinggi sebagai orde yang akan digunakan. Tabel 4. menunjukan $\mathrm{R}^{2}$ dari orde 0 lebih tinggi dibanding orde 1 , sehingga dipilih orde 0 yang artinya bersifat linier.

\section{Laju Perubahan Mutu pH}

pH menunjukkan konsentrasi ion hidrogen yang merupakan gambaran tingkat keasaman cuka. $\mathrm{pH}$ yang semakin tinggi menunjukkan tingkat keasaman cuka semakin rendah (Dewi, 2015). Laju perubahan mutu pH cuka kakao hasil samping cairan pulpa kakao orde 0 dan orde 1 dapat dilihat pada Gambar 3.

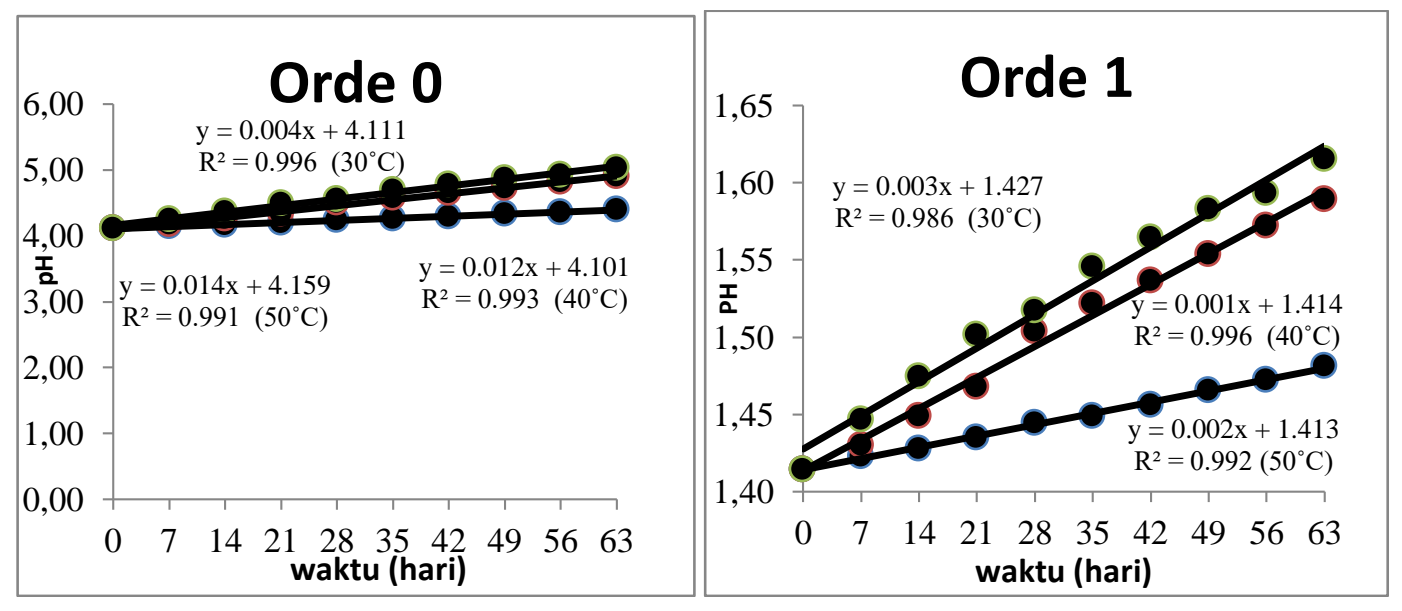

Gambar 3. Laju perubahan mutu pH cuka kakao orde 0 dan orde 1.

Perubahan $\mathrm{pH}$ terjadi karena kondisi suhu dan lama penyimpanan menyebabkan $\mathrm{pH}$ mengalami peningkatan, antosianin dalam cuka mengalami degradasi sehingga menyebabkan $\mathrm{pH}$ menjadi meningka. Suhu yang semakin tinggi menyebabkan konformasi struktur antosianin, yang tidak stabil (Fennema, 2008). Persamaan regresi linier karakteristik pH dapat dilihat pada Tabel 3

Tabel 3. Persamaan Regresi Linear Karakteristik pH

\begin{tabular}{cccccc}
\hline \multirow{2}{*}{ Parameter } & Suhu & \multicolumn{2}{c}{ Persamaan Regresi } & \multicolumn{2}{c}{$\mathrm{R}^{2}$ (R square) } \\
\cline { 3 - 6 } & $\left({ }^{\circ} \mathrm{C}\right)$ & Orde 0 & Orde 1 & Orde 0 & orde 1 \\
\hline \multirow{2}{*}{$\mathrm{pH}$} & 30 & $\mathrm{y}=0.0044 \mathrm{x}+4.1117$ & $\mathrm{y}=0.001 \mathrm{x}+1.4142$ & 0.9961 & 0.9968 \\
& 40 & $\mathrm{y}=0.0129 \mathrm{x}+4.1012$ & $\mathrm{y}=0.0029 \mathrm{x}+1.4137$ & 0.9937 & 0.992 \\
& 50 & $\mathrm{y}=0.0142 \mathrm{x}+4.1595$ & $\mathrm{y}=0.0031 \mathrm{x}+1.4278$ & 0.9916 & 0.9864 \\
\hline
\end{tabular}

Berdasarkan Tabel 3, Menunjukan koefisien $\mathrm{R}^{2}$ dari orde 0 lebih besar dari koefisien orde 1, sehingga perhitungan untuk mendapatkan umur simpan cuka kakao hasil samping cairan pulpa 
menggunakan persamaan reaksi pada orde 0 yang bersifat linier dimana $\mathrm{pH}$ mengalami peningkatan secara garis lurus. (Haryati et al., 2015).

\section{Laju Perubahan Total Padatan Terlarut ( ${ }^{\circ}$ Brix)}

Total Padatan Terlarut menunjukkan peningkatan padatan terlarut terjadi karena penurunan kadar asam asetat yang dipengaruhi oleh suhu dan lama penyimpanan. Semakin tinggi suhu dan lama simpan maka akan menyebabkan peningkatan total padatan terlarut. (Haumasse 2009). Laju perubahan total padatan terlarut orde 0 dan orde 1 dapat dilihat pada Gambar 4.

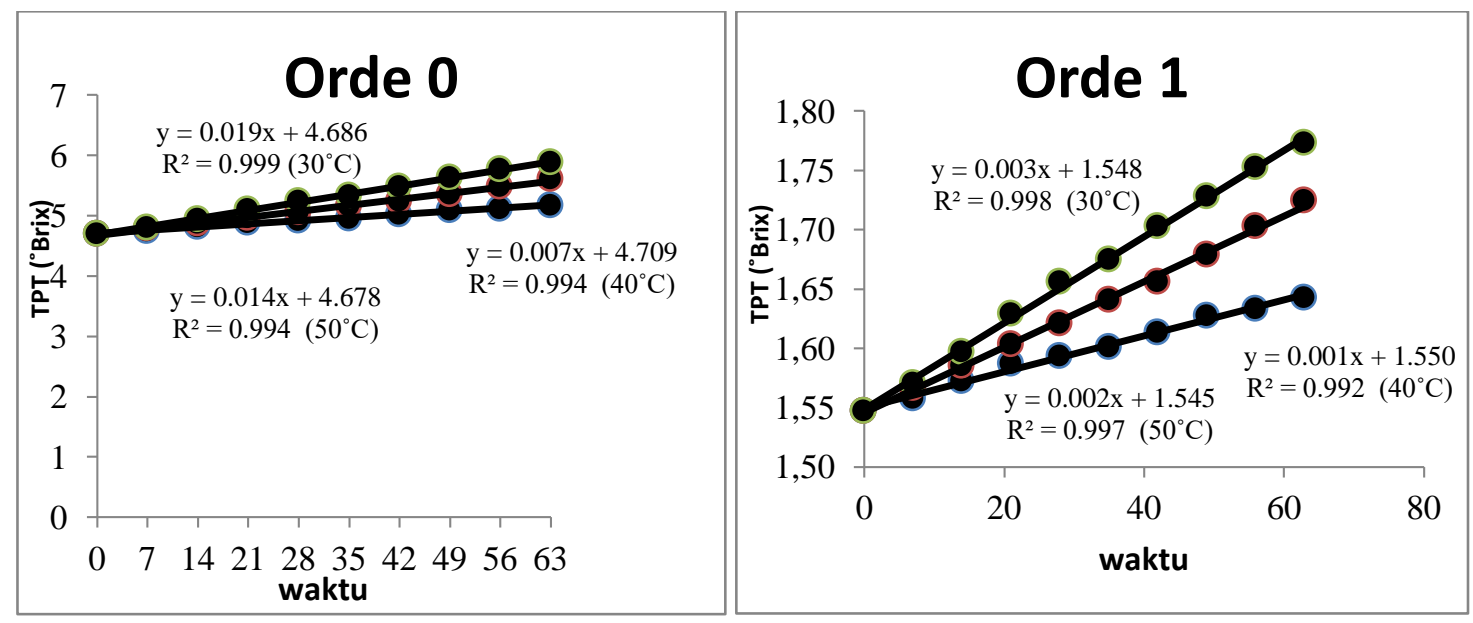

Gambar 4. Perubahan total padatan terlarut pada orde 0 dan orde 1

Gambar 4. Menunjukkan total padatan terlarut ${ }^{\circ}$ Brix, mengalami peningkatan seiring dengan kondisi suhu dan lama penyimpanan. Hal ini disebabkan karena aktifitas khamir mulai terhambat pada konsentrasi yang lebih tinggi. Persamaan regresi linier karakteristik TPT $\left({ }^{\circ}\right.$ Brix) dapat dilihat pada Tabel 4.

Tabel 4. Persamaan Regresi Linear Karakteristik Total Padatan Terlarut ( ${ }^{\circ}$ Brix $)$

\begin{tabular}{cccccc}
\hline \multirow{2}{*}{ Parameter } & \multirow{2}{*}{\begin{tabular}{c} 
Suhu \\
\cline { 3 - 6 }
\end{tabular}} & \multicolumn{2}{c}{ Persamaan Regresi } & \multicolumn{2}{c}{$\mathrm{R}^{2}$ (R square) } \\
\cline { 3 - 6 } & 30 & $\mathrm{y}=0.0074 \mathrm{x}+4.7095$ & $\mathrm{y}=0.0015 \mathrm{x}+1.5502$ & 0.9942 & 0.9929 \\
Total & 30 & $\mathrm{y}=0.0142 \mathrm{x}+4.6787$ & $\mathrm{y}=0.0028 \mathrm{x}+1.5456$ & 0.9949 & 0.9976 \\
padatan & 40 & $\mathrm{y}=0.0192 \mathrm{x}+4.6869$ & $\mathrm{y}=0.0036 \mathrm{x}+1.5488$ & 0.9991 & 0.9982 \\
terlarut & 50 & $\mathrm{y}=0.0$ &
\end{tabular}

Umur simpan cuka untuk karakteristik total padatan terlarut dilakukan dengan menentukan orde reaksi $\mathrm{R}^{2}$ nya. Penentuan umur simpan cuka kakao berdasarkan karakteristik total padatan terlarut, digunakan persamaan orde 0 karena $\mathrm{R}^{2}$ orde 0 lebih besar dibanding orde 1 .

\section{Laju Perubahan Kekeruhan}

Kekeruhan menunjukkan peningkatan kekeruhan pada cuka kakao yang terbaca melalui absorbansi yang dihasilkan mengalami peningkatan. Hal ini disebabkan karena pengaruh suhu dan lama penyimpanan menyebabkan total padatan terlarut meningkat dan nilai absorban meningkat. Menurut Febriyansari (2008), panjang gelombang digunakan untuk melihat tingkat kekeruhan pada larutan yang 
berwarna kuning sampai coklat. Laju perubahan mutu nilai kekeruhan cuka kakao hasil samping cairan pulpa kakao orde 0 dan orde 1 dapat dilihat pada Gambar 5.

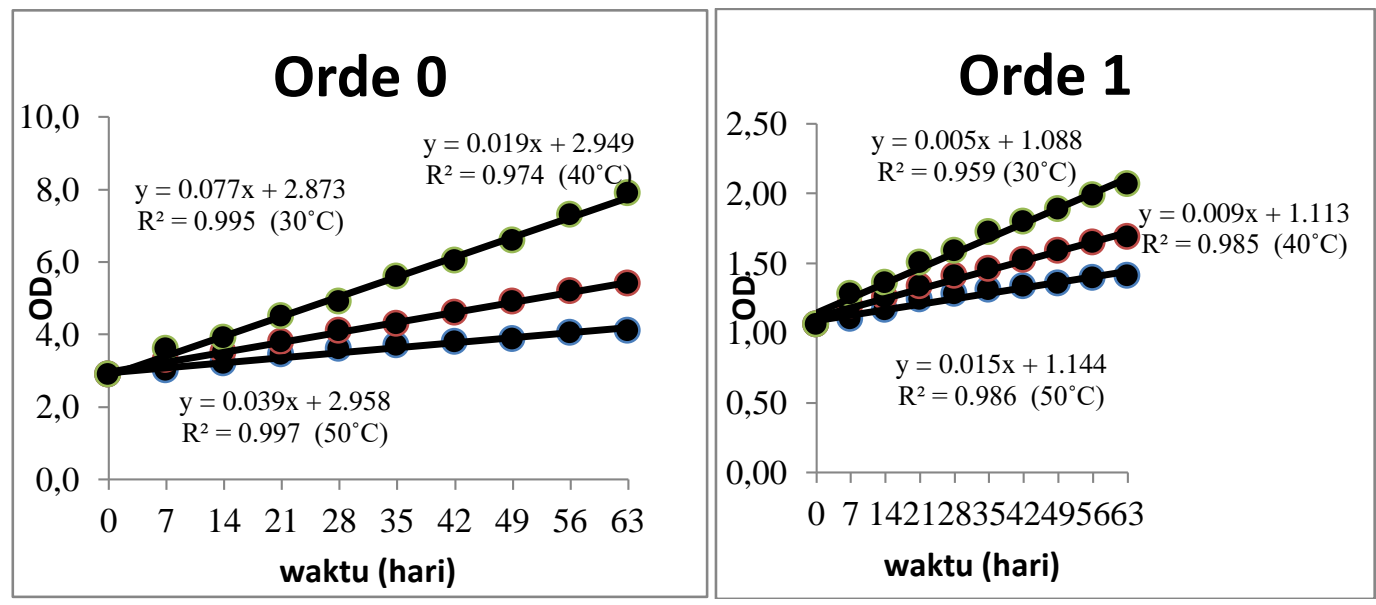

Gambar 5. Perubahan mutu kejernihan cuka kakao orde 0 dan orde 1.

Gambar 5. menunjukan terjadinya peningkatan kekeruhan (OD) selama penyimpanan. Persamaan regresi linier kekeruhan (OD) dapat dilihat pada Tabel 5.

Tabel 5. Persamaan Regresi Linear Karakteristik Kekeruhan (OD)

\begin{tabular}{cccccc}
\hline \multirow{2}{*}{ Parameter } & \multirow{2}{*}{$\begin{array}{c}\text { Suhu } \\
\left({ }^{\circ} \mathrm{C}\right)\end{array}$} & \multicolumn{2}{c}{ Orde 0 } & Orde 1 & \multicolumn{2}{c}{$\mathrm{R}^{2}(\mathrm{R}$ square $)$} \\
\cline { 3 - 6 } & 30 & $\mathrm{y}=0.0196 \mathrm{x}+2.9493$ & $\mathrm{y}=0.0056 \mathrm{x}+1.0882$ & 0.9742 & 0.9592 \\
\multirow{3}{*}{ Kekeruhan } & 40 & $\mathrm{y}=0.0394 \mathrm{x}+2.9584$ & $\mathrm{y}=0.0096 \mathrm{x}+1.1132$ & 0.9976 & 0.9859 \\
& 50 & $\mathrm{y}=0.0777 \mathrm{x}+2.8735$ & $\mathrm{y}=0.0153 \mathrm{x}+1.1447$ & 0.9959 & 0.986 \\
\hline
\end{tabular}

Berdasarkan Tabel 5, Kekeruhan (OD) dilakukan dengan menentukan orde reaksi $\mathrm{R}^{2}$ nya untuk penentuan umur simpan cuka karakteristik kejernihan, digunakan persamaan orde 0 karena nilai $\mathrm{R}^{2}$ orde 0 lebih besar dari orde 1 . Terjadinya peningkatan kekeruhan secara garis lurus yang bersifat linier.

\section{Persamaan Arrhenius dan Energy Aktivasi}

Karakteristik yang ditentukan berdasarkan penurunan mutu cuka selama penyimpanan yang telah diamati dengan beberapa karakteristik adalah, kadar asam asetat, $\mathrm{pH}$, padatan terlarut (TPT) dan kekeruhan. Untuk dapat menentukan karakteristik mana yang memiliki energi aktivasi (Ea) terendah. Dapat dilihat pada grafik persamaan Arrhenius dari masing-masing suhu. Grafik persamaan Arrhenius cuka kakao (kadar asam asetat, $\mathrm{pH}$, total padatan terlarut dan kekeruhan) dapat dilihat pada Gambar 6, 7, 8, dan 9.

Persamaan regresi linear dari plot $\ln \mathrm{k}$ dan 1/T pada perubahan kadar asam asetat cuka kakao yaitu $\mathrm{y}=-4624 \cdot \mathrm{x}+10,30$ dengan $\mathrm{R}^{2}=0,999$. Untuk memulai terjadinya perubahan kadar asam asetat, Energi aktivasinya (Ea) sebesar $9219806,4 \mathrm{kal} / \mathrm{mol}$. 


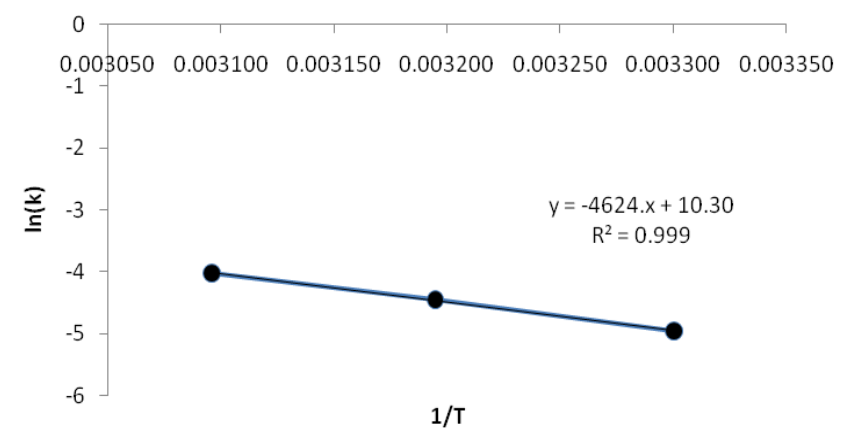

Gambar 6. Grafik persamaan Arrhenius Kadar Asam Asetat

Persamaan regresi linear dari plot ln $\mathrm{k}$ dan $1 / \mathrm{T}$ pada perubahan $\mathrm{pH}$ cuka kakao yaitu $\mathrm{y}=-5782, \mathrm{x}+$ 13,81 dengan $\mathrm{R}^{2}=0,825$. Dimana, untuk memulai terjadinya perubahan $\mathrm{pH}$, Energi aktivasinya (Ea) sebesar 11094987,6 kal/mol.

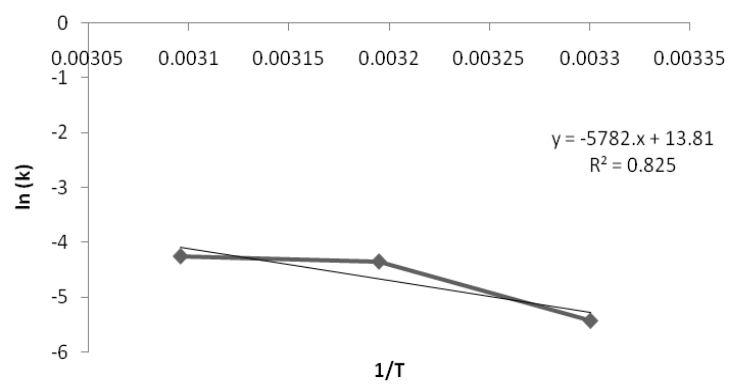

Gambar 7. Grafik persamaan Arrhenius pH cuka kakao

Persamaan regresi linear dari plot $\ln \mathrm{k}$ dan 1/T pada perubahan TPT cuka kakao yaitu y = 4682x $+10,59$ dengan $\mathrm{R}^{2}=0,964$. Dimana, untuk memulai terjadinya perubahan TPT, Energi aktivasinya (Ea) sebesar $9298849,2 \mathrm{kal} / \mathrm{mol}$.

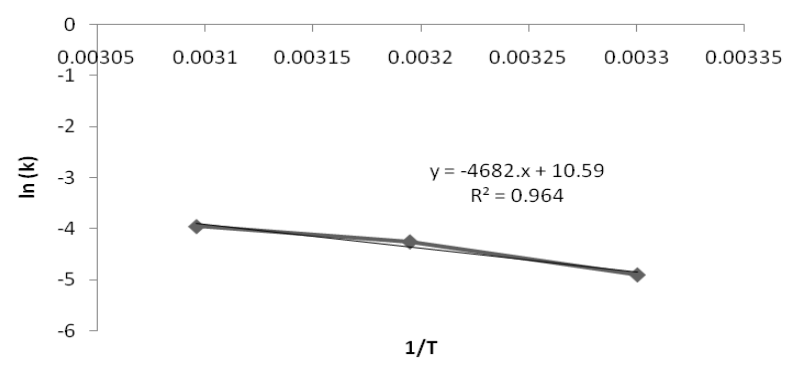

Gambar 8. Grafik persamaan Arrhenius TPT cuka kakao

Persamaan regresi linear dari plot $\ln \mathrm{k}$ dan $1 / \mathrm{T}$ pada perubahan kekeruhan cuka kakao yaitu $\mathrm{y}=$ $6738 \mathrm{x}+18,30$ dengan $\mathrm{R}^{2}=0,999$. Dimana, untuk memulai terjadinya perubahan OD, Energi aktivasinya (Ea) sebesar $13382860 \mathrm{kal} / \mathrm{mol}$.

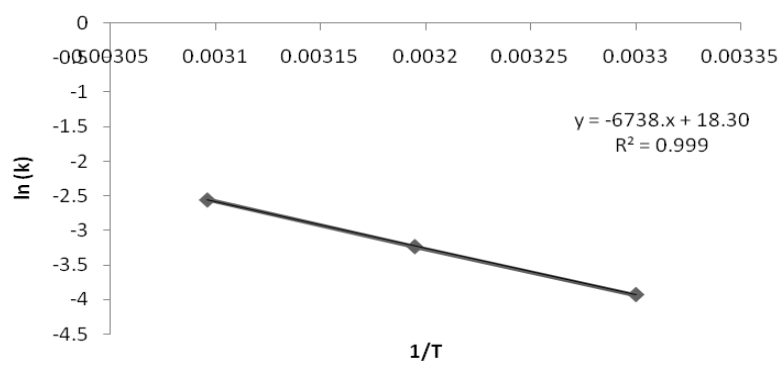

Gambar 9. Grafik persamaan Arrhenius OD cuka kakao 
Karakteristik penentuan umur simpan cuka kakao hasil samping cairan pulpa kakao ditentukan berdasarkan karakteristik yang memiliki Energi Aktivasi (Ea) terendah (Kusnandar, 2010). Diketahui bahwa kadar asam asetat memiliki Energi aktivasi (Ea) terendah. Persamaan linier untuk karakteristik asam asetat adalah $\mathrm{y}=-4624 . \mathrm{x}+10,30$ dengan $\mathrm{R}^{2}=0,999$. Berdasarkan persamaan regresi arrhenius dan energy aktivasi (Ea) cuka kakao hasil samping cairan pulpa dapat dilihat pada Tabel 6 ,

Tabel 6. Persamaan Arrhenius dan Energi Aktivasi (Ea) cuka kakao hasil samping cairan pulpa

\begin{tabular}{lcc}
\multicolumn{1}{c}{ Parameter } & \multicolumn{1}{c}{ Persamaan } & $\begin{array}{c}\text { Energi } \\
\text { Aktivasi (Ea) }\end{array}$ \\
\hline Asam Asetat & $\ln (k)=10,309-4624,4(1 / T)$ & 9219806,40 \\
pH & $\ln (k)=11,685-5586,6(1 / T)$ & 1109498,76 \\
TPT & $\ln (k)=10,598-4682,2(1 / T)$ & 9298849,20 \\
Kekeruhan & $\ln (k)=18,303-6738,6(1 / T)$ & 1338286,00 \\
\hline
\end{tabular}

\section{Penentuan Umur Simpan Cuka Kakao}

Penentuan umur simpan cukakakao dihitung menggunakan persamaan regresi linier berdasarkan karakteristik yang terpilih. Berdasarkan perhitungan didapatkan karakteristik untuk penentuan umur simpan cuka kakao berada pada kadar asam asetat dengan orde reaksi ke-0. Persamaan regresi linier kadar asam asetat cuka kakao adalah $\mathrm{y}=-4624 \mathrm{x}+10,30$ dengan $\mathrm{R}^{2}=0,999$ dan Energi Aktivasi (Ea) sebesar 9219806,4 kal/mol. Persamaan yang didapat kemudian digunakan untuk mendapatkan nilai $\mathrm{k}$ pada setiap suhu penyimpanan sehingga akan diperoleh umur simpan cuka kakao pada Tabel 7. yang menunjukkan hasil perhitungan umur simpan cuka kakao pada berbagai suhu penyimpanan.

Tabel 7. Umur simpan cuka kakao

\begin{tabular}{ccccc}
\hline \multirow{2}{*}{ Suhu $\left({ }^{\circ} \mathrm{C}\right)$} & \multirow{2}{*}{$\mathrm{K})$} & Hari & Minggu & Bulan \\
\cline { 3 - 5 } & 0.002253569 & 431 & 61,57 & 14,3 \\
20 & 0.003944754 & 246 & 35,14 & 8,20 \\
30 & 0.006654565 & 146 & 20,85 & 4,86 \\
40 & 0.010856961 & 89 & 12,71 & 2,96 \\
50 & 0.017184363 & 56 & 8,00 & 1,86 \\
\hline
\end{tabular}

\section{KESIMPULAN DAN SARAN}

\section{Kesimpulan}

1. Cuka kakao hasil samping cairan pulpa kakao mengalami penurunan mutu selama penyimpanan. pada suhu $30^{\circ} \mathrm{C}, 40^{\circ} \mathrm{C}$ dan $50^{\circ} \mathrm{C}$. Selama penyimpanan dari ketiga suhu tersebut, suhu $50^{\circ} \mathrm{C}$ mengalami kerusakan paling cepat dengan karakteristik penurunan kadar asam asetat lebih dari $50 \%$, serta adanya peningkatan $\mathrm{pH}$, TPT dan kekeruhan pada hari ke-63.

2. Hasil penentuan umur simpan cuka kakao dengan menggunakan karakteristik kadar asam asetat dengan persamaan regresi linier $y=-4624 . x+10,30$ dengan $R^{2}=0,999$, pada penyimpanan suhu $10^{\circ} \mathrm{C}, 20^{\circ} \mathrm{C}, 30^{\circ} \mathrm{C}, 40^{\circ} \mathrm{C}$, dan $50^{\circ} \mathrm{C}$ berturut-turut adalah 431 (14,3 bulan), 246 hari $(8,20$ bulan), 146 hari (4,86 bulan), 89 hari (2,96 bulan), dan 56 hari (1,86 bulan). 


\section{Saran}

Penelitian lebih lanjut mengenai proses penyimpanan cuka kakao hasil samping dari cairan pulpa kakao dengan menggunakan metode Accelerated Self-Life Testing (ASLT) dengan pendekatan Arrhenius perlu dilakukan menggunakan suhu dan lama penyimpanan dengan tingkatan yang berbeda serta penggunaan kemasan produk yang berbeda pula. Kepada para pelaku industri, diharapkan dapat menentukan umur simpan cuka dengan menekankan pada perubahan asam asetat sebagai parameter mutu kritis, sehingga pelaku industri dapat mengamati perubahan mutu cuka selama proses penyimpanan berlangsung, untuk mengurangi resiko kerusakan.

\section{DAFTAR PUSTAKA}

Aridona, P.M., N.M. Wartini dan I W. Arnata. 2015. Pengaruh Lama Fermentasi Alami Cairan Pulpa Hasil Samping Fermentasi Biji Kakao terhadap Rendemen dan Karakteristik Cuka Fermentasi. Jurnal Rekayasa Dan Manajemen Agroindustri. 3(3):85-92.

Case, C.L. 2004. The Microbiology of Chocolate. https://accounts.smccd.edu/case/chocolate.html. Diakses tanggal 01 Januari 2017.

Ganda-Putra, G.P., Harijono, S. Kumalaningsih dan Aulani'am. 2008. Optimasi Kondisi Depolimerisasi Pulp Biji Kakao oleh Enzim Poligalakturonase Endojinus. Jurnal Teknik Industri. 9 (1):24-34.

Haumasse, M. 2009. Pemanfaatan Pulpa Kakao untuk Memproduksi Asam Asetat dengan Menggunakan Ragi Roti dan Aerasi. Tesis S2. Sekolah Pascasarjana Institut Pertanian Bogor, Bogor.

Haryati. 2014. Penentuan Suhu dan Waktu Sterilisasi pada Produk Tape Ketan Hitam Khas Mojokerto. Skripsi. Universitas Brawijaya. Malang.

Haryati, E.Teti, H. Feronika,. dan K.Ahmadi. 2015. Pendugaan Umur Simpan Menggunakan Metode Accelerated Shelf-Life Testing (ASLT) Dengan Pendekatan Arrhenius Pada Produk Tape Ketan Hitam Khas Mojekerto Hasil Sterillisasi. Jurnal Pangan dan Agroindustri. 3(1):156-165

Herawati, H. 2008. Penentuan Umur Simpan pada Produk Pangan. Jurnal Litbang Pertanian. 27:4

James, C.S. 1995. Analytical Chemistry of Foods. Blackie Academic \& Professional, London.

Kwartiningsih, E. dan L.N.S. Mulyati. 2005. Fermentasi Buah Nanas Menjadi Vinegar. Ekuilibrium. 4(1): $8-12$.

Luwihana, S., K.R. Kuswanto, E.S. Rahayu dan S. Sudarmadji. 2010. Fermentasi Asam Asetat Dengan

Sel Amobil Acetobacter pasteurianus INT-7 dengan Variasi pH Awal Dan Kadar Etanol. Agritech. 30(2): 123-132.

Nurismanto, R., T. Mulyani dan D.I.N. Tias. 2014. Pembuatan Asam Cuka Pisang Kepok (Musaparadisiaca L.) dengan Kajian Lama Fermentasi Dan Konsentrasi Inokulum (Acetobacteracetii). Jurnal Rekapangan. 8(2):149-155.

Putri, A.G.S.I.M., G.P. Ganda-Putra dan W. Arnata. 2016. Pengaruh Penambahan Inokulum Saccharomycess cerevisiae Dan Lama Fermentasi terhadap Karakteristik Cuka Fermentasi dari Cairan Pulpa Hasil Samping Fermentasi Biji Kakao (Theobroma Cacao L). Jurnal Rekayasa dan Manajemen Agroindustri. 4(3):71-84. 
Sandana, F.B., D, Rawung., M, Lodong., dan C, Mamuja. 2011. Penentuan Umur Simpan Sirup Pala Menggunakan Metode ASLT (Accelerated Shelf Life Testing) Dengan Pendekatan Arrhenius. Skripsi S1. Tidak dipublikasikan. Program Studi Ilmu dan Teknologi Pangan Universitas Sam Ratulangi, Sulawesi Utara.

SNI 01-3711-1995. Standar Nasional Indonesia (SNI) Cuka Makan. Badan Standardisasi Nasional (BSN), Jakarta.

SNI 01-4371-1966. Standar Nasional Indonesia (SNI) Cuka Fermentasi. Badan Standardisasi Nasional (BSN), Jakarta.

Sudarmadji, S., B. Haryono dan Suhardi. 1989. Analisis Bahan Pangan dan Hasil Pertanian. Liberty, Yogyakarta.

Susilowati, A., dan P. A. Wati. 2001. Kajian Awal Pembuatan "Vinegar" dari Air Kelapa dan Limbah Cair Pembuatan "Nata de Coco" dengan Metode "Quick Process". Biosmart. 3(2):13-17.

Waluyo, S. 1984. Beberapa Aspek Tentang Pengolahan Vinegar. Dewaruci Press, Jakarta.

Wartini, N.M., L.P. Wrasiati dan A.A.M.D. Anggreni. 2014. Petunjuk Praktikum Pengetahuan Bahan Pangan. Jurusan Teknologi Industri Pertanian. Fakultas Teknologi Pertanian. Universitas Udayana. Bukit Jimbaran.

Yellisa, M. 2014. Produksi Asam Asetat Secara Fermentasi. http://www.slideshare.net/meidina_yellisa/produksi-asam-asetat-secara-fermentasi. Diakses tanggal 7 Februari 2017. 